Volume: 7

Nomor : 2

Bulan : Mei

Tahun : 2021

\title{
Philosophy of Yoga as Education in The Perspective of Javanese Community Life
}

\author{
Sawitri \\ Sutarman \\ R. Adi Deswijaya \\ Universitas Veteran Bangun Nusantara Sukoharjo \\ Universitas Islam Syekh Yusuf \\ Pos-el: putrisawitriku@g.mail.com \\ sutarman@unis.ic.id \\ adides2016@gmail.com
}

\section{DOI: 10.32884/ideas.v7i2.336}

\begin{abstract}
Abstrak
Beryoga adalah sebagai filosofi masyarakat Jawa dan sebagai olahraga yang tertumpu pada pernapasan dan peregangan urat sarap serta kelenturan organ tubuh, gerakan yang membuat gerakan berat jadi ringan. Tujuan penelitian ini adalah untuk mengetahui: (1) filosofi yoga; (2) pendidikan sebagai budaya dan pengetahuan beryoga; (3) masyarakat Jawa dalam mendapatkan kenyamanan hidup. Simpulan yang didapat ialah filosofi yang ada pada yoga adalah: (1) menyatukan pernapasan, hati, dan jiwa; (2) membuat ketenteraman hati dan jiwa; (3) beryoga merupakan sarana yang positif untuk mencerahkan pola pikir dan perilaku masyarakat Jawa; (4) budaya beryoga sebagai peninggalan nenek moyang dan leluhur masyarakat Jawa menjadikan bersih hati dan jiwa, serta berperilaku yang baik. Hal ini akan membuat hidup menjadi sejahtera dan dapat menyembuhkan penyakit jantung, stres, asma, bahkan tekanan pada suatu pekerjaan. Stres pada remaja, ibu hamil, dan orang dewasa, bahkan orang yang sudah tua.
\end{abstract}

\section{Kata Kunci}

Filosofi beryoga, pendidikan, masyarakat Jawa

\begin{abstract}
Yoga is a philosophy of Javanese society and as a sport that focuses on breathing and stretching breakfast and organ flexibility, movements that make heavy movements light. Purpose of this study is to find out: (1) philosophy of yoga; (2) education as a culture and knowledge of yoga; (3) Javanese society in getting the comfort of life. The conclusion is the philosophy which exists in yoga is: (1) uniting breathing, heart and soul; (2) yoga can make peace of heart and soul; (3) yoga is a positive means of enlightening the mindset and behavior of Javanese society (4) the culture of yoga is a legacy of the ancestors and ancestors of the Javanese people. Make the heart clean and soul clean and have good behavior. This will make life prosperous and can cure heart disease, stress, asthma and even stress at work. Stress in adolescents, pregnant women and adults and even older people.
\end{abstract}

Keywords

Philosophy of yoga, education, javannese community

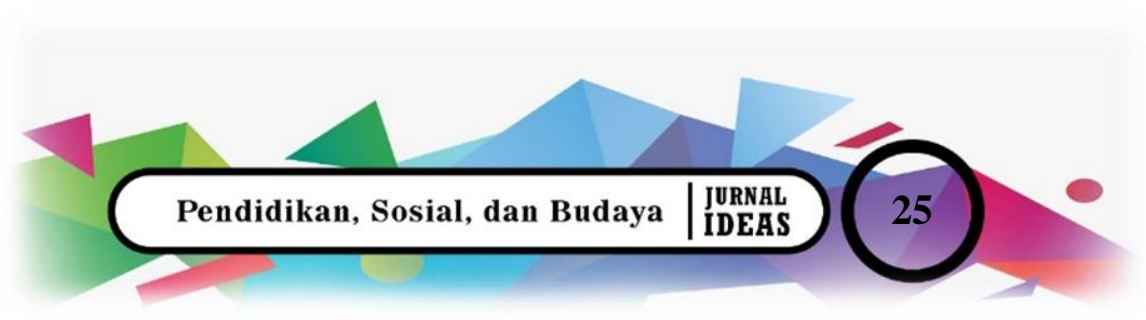


ZE E-ISSH: 2656-940X

D) P-ISSH: 2442-367K

URL: jurnal.ideaspublishing.co.id
Volume : 7

Nomor : 2

Bulan : Mei

Tahun : 2021

\section{Introduction}

Society is a community that is grouped in a certain group and has relatively the same goals and life background. People are looking for a place to live according to the cultural background of their supporters. Javanese community life is life in groups within a community or group who live in a certain area, live comfortably, safely and also live according to the rules of a community or social group. Javanese society is a group or community that lives in a place with a relatively similar cultural background that remains obedient and always puts forward Javanese culture that is noble and culture as ancestral heritage to be preserved (Kuntowijoyo, 2006).

Javanese society is a community that still prioritizes Javanese activities and behavior. A life that is in harmony with cultural life that upholds moral ethics, behavior that is polite and has personality. Javanese people are very close to Javanese culture. One of the works of cultural results is that language and language are translated back into the form of a proverb. Javanese proverb which contains the teachings of life for Javanese people to be used as an example of behavior and ethics in life.

The Javanese proverb is a work that is full of meaning and contains the teachings of life. Life according to a real order and rules not in writing. Javanese proverbs that contain the philosophy of life can be used as a view of life for Javanese people. Guided by proverbs that provide views and examples in a good life. Dignified behavior, in accordance with the rules of life guided by the life of Javanese society. The view of life is a foothold or qibla to imitate a good past life that is ethical and cultured. The life that is lived is inseparable, remembering the past life, which was not good enough to be left behind and the good life can be continuously improved to become a better person. A good person will motivate others (Denzin, K. Nurman., et al., 2009).

The philosophy of life in Javanese society is very important in determining the direction of life to be lived. A life that runs according to the rules that are sometimes difficult to do, then the direction of life and life goals must be determined so that life remains in the real life of a good life. Life is a choice and this Javanese people can apply life in Javanese proverbs to the daily life of the state, in society and also in family life.

Philosophy is a theory of life or a person's worldview affecting state life. The philosophy that is awakened in oneself will color how nationalism lives. View of life is influenced by various information in religious teachings. View of life is a goal in human life. View of life is also a hope that wants to manifest in the mind but becomes an essential thing to do and live in.

The philosophy according to KBBI is an assumption, idea and the most basic inner attitude possessed by a person or society as a way of life. The philosophy of deep thought about something by expressing thoughts that can be used as a view of life in society.

Javanese proverbs are a form of language style that is often used by Javanese people to give advice, reprimand or satire to others (Sawitri et al., 2018). The form of this Javanese proverb is in the form of a group of words that are short, dense, and contain various norms that can be learned as life lessons. Javanese proverbs contain messages of wisdom and positive values in them. Until now, it is still well preserved and thick in people's lives (Bengat, 2014). 
Javanese proverbs are commonly used by parents in advising their children, as well as in giving insinuations or admonitions to someone (Sawitri et al., 2019). The form of Javanese proverbs is a bit concise and easy to memorize, but it has a dense meaning, and the style of speech sometimes hits the heart. A satire proverb and give advice to Javanese people to give examples of good behavior and inappropriate behavior in the life of society, nation and state.

The community is a group of people who live in a group by obeying certain rules and obeying customary rules so that life runs according to the agreed rules. The operation of a group in a certain community that runs according to the rules will make social life balanced and harmonious so that there is no dispute, misunderstanding because there is an agreement even though it is not written. Humans who are a community will obey a rule because it becomes an agreement between one group and another. Community groups will live together and there are agreements for goals in society (Sahlan, A., 2002).

The view of life in Javanese society is something that is used as a guideline and used as a foundation in daily life for living in society, as a nation and as a state. View of life is an essential guide so that life will continue to run well. Living a comfortable, safe and peaceful life can not be separated from a belief to be good. Living in accordance with the philosophy of life of the Javanese people gets a calm, comfortable and peaceful life in their life (Patrick J. M. Costello., 2007). Harmony in social life will create comfort from all parties.This is in accordance with multicultural-based cultural learning, namely that in culture there are cultural existence that can be emulated for learning, namely doing good with others, respecting others, being kind, maintaining ethics and politeness and politeness (Yanti, 2018).

In Javanese culture, which is related to a philosophy of life, it will make humans have a good personality and in accordance with the behavior of Javanese people who uphold ethics. Behavior in ethics can be seen in the lyrics of the keroncong song written by Waljinah, whose lyrics are inspiring to live by being kind (Bengat, et al., 2014). It is fitting for the teachings of Javanese life. Good behavior can also be used for the next generation of students because good ethics are found in Javanese society and become a philosophy of life. A good child's life, a shining future and the aspirations of life can be achieved, students who are smart and have broad insight and have a view of life that is in accordance with the life of Javanese society and a good personality (Coles, H. William., 2016).

People who have the same view of life will live with one group while those who think of another life but are included in one group will create problems and this makes life uncomfortable. Comfort will be created if the outlook on life is the same. We should avoid having different views within the group to avoid misunderstanding, confusion and even different perceptions and goals in life. The background of the community is also the key word that the outlook on life can be different. We will be able to avoid differences as long as there is awareness in society even though the outlook on life is different. Concerned with the interests of many people compared to personal or group interests. The philosophy in Javanese paribasan, freedom and saloka can be used as a view of life and Javanese culture contained therein as a form of local wisdom from a Javanese culture so that it should be respected, imitated and also carried out (Prasetyo \& Ginting, 2019) 


\section{Methods}

The research method used a qualitative approach. To reveal and produce descriptive information or data (Sutopo, 2006:64).

1. Data collection techniques through namely:

a. Interviews with respondents in the form of words that are seen and observed that produce data.

b. Observations of data collection were obtained from the field

c. Literature study as a complement in improving data.

d. Documents in the form of books, journals, photos and others are used to complement the data, and are classified and analyzed according to what is obtained in the field.

\section{Data verification}

Data verification was obtained from interviews, observations and literature studies. So that the data can really be used as evidence (Miles, M. B., et al., 2014).

\section{Results and Discussion \\ Results}

The proverb of patient sareh mesthi will be used, meaning that those who behave patiently will definitely benefit and the sweet fruit of patience.The proverb is Ngundhuh wohing pakarti, whatever is done will yield a commensurate resultThe proverb rukun agawe santosa crah agawe bubrah, means living in harmony with others will get a safe, comfortable life

The proverb tuna sathak bathi kinsman, means doing good to anyone, whether it's orange, good with us or not, but we must always be good and we think like brothers. The proverb ana dina ana upa, there are days of rice, which means that as long as people want to work diligently they will definitely get a bite of rice (fortune).The proverb of ora obah ora mamah (not wanting to move will not eat), that is, you have to keep the spirit of work so that there is always good fortune coming.

The Javanese proverb that can be expressed in it is a Javanese philosophy of ngundhuh wohing pakarti (picking the fruit of one's own deed), meaning that when farmers plant rice, they will reap rice instead of corn. An allusion to someone who does bad deeds is sure to get bad things too in the future.The proverb of kebo gupak ajak - ajak (a muddy buffalo invites dirty in contact with it), meaning this expression is a warning that people who have bad (dirty) characteristics and actions tend to like to invite (influence) others to follow their actions, therefore or not close.

The proverb of the child polah father kepradah (the child asks the parents to pass it), meaning that a warning for parents must carefully consider the child's request, regarding good and bad and its benefits, so as not to cause problems in the family.The proverb witing tresna jalaran saka kulina, (the beginning of love because it is usually close together), means a warning for both men and women to be careful in making friends, because closeness (intimacy) can grow love.The proverb of nabok nyilih hands, (meukul borrows the hands of others), means the metaphor of a cunning person who does not dare to face his enemies openly, but asks for help (help) from others secretly. 


\section{Discussion}

The proverb of kekudhung walulang tiger, (hooded with tiger skin), means a picture of a person trying to achieve his desires by using the influence of a ruler or a person who is feared by society.The proverb becik ketitik ala ketara, (good will be proven) is acknowledged, bad will show itself), which means the suggestion that anyone is not afraid to do good even though it is not visible at first, in time they will find meaning and be appreciated, if they do badly, their cleverness will eventually be caught.The proverb of emban cindhe, emban siladan (carrying with a scarf, carrying with a bamboo sharpener) is advice aimed at parents (rulers) so as not to differentiate their attention to children or the people. (subordinates), those who are liked should not be given convenience while those who are not liked are continuously hurt (made difficult) in their life.

The proverb of Kegedhen empyak is not forged. (the oversized roof lacks poles) is a ruah which means a picture of a person who does something more than his ability to force himself as a house whose roof is too large (wide) with a few (small) poles. so that his dreams cannot be realized, the house can stand but it collapsed and created new problems. The proverb ngono yo ngono, ning aja ngono, (so yes, but not) means that this expression is a warning not to overdo it so that it creates new problems or disturbs others. An example of a person who collects a debt that has not been paid for a long time but should not be done solely in public, because it will embarrass the person who bills it.

The proverb of dudu kinsman dudu sometimes, the yen dies over and over. (not relatives, not relatives, if you die you will also lose it), meaning that even if you don't, if you get hurt, you will be sad and lost.The proverb of kesandhung ing rata kebentus ing tawang, stumbling on a flat place, hit the sky, means an event that is rare and impossible to occur due to carelessness and carelessness. It is a warning so that people are always alert and careful in doing something. The proverb prevents dhahar versus bolsters from reducing eating and sleeping, which means that the fasting model holds back the lust that complements everyday life so that your wishes come true and life becomes better.The proverb janma tan kena ingina (humans should not be insulted), a warning that people may differ in content and appearance may be mistaken because many people like to hide it or keep it, abilities that are far different from what they appear to be.

Revealing from the contents of paribasan, liberation and Javanese saloka can be the view of life of the Javanese people because the contents of paribasan, liberation and Javanese saloka that have been described above contain Javanese philosophy to be used as a way of life. The contents and teachings in it contain values to set an example in the life and behavior of Javanese society. Behavior in accordance with the Javanese philosophy will make life harmonious, comfortable, and life harmonious. Harming people, insulting people is not allowed in religion as well and society believes that people who hurt others will also be hurt by people, doing good is the duty of every human being. An attitude of loving each other will provide a comfortable life for others. Avoid distinguishing work status, this wealth will create divisions. Having aspirations must be with enthusiasm and prayer and effort, this can be a way to realize hopes and ideals, for example, just dreams that will not come true, the 
philosophy of goodness can be used as a moving mirror so that what becomes an ideal is realized. The philosophy in Javanese paribasan, freedom and saloka is very suitable and very good for the Javanese view of life. Noble values are contained in paribasan, freedom and Javanese saloka to make a wish come true. Life can be safe, peaceful and prosperous in life.

\section{Conclusion}

Proverbs can be used as a philosophy for Javanese life and from a deep philosophy for Javanese life that can be used as a guide in life. Community life in harmony with the life of the Javanese. A life that puts forward a cool, comfortable life is like a life that is far from a hasty mindset, in deciding a problem but with a mature mind to be able to move forward, striving for a peaceful life that does not harm yourself and others and even society Another Javanese. In terms of the Javanese view of life above, it can be used as a view of life for the Javanese people.

Living in accordance with the philosophy in the proverb above can be a guide and guide as well as a goal in a better life. A life that is as comfortable and smooth as will make this life essential. Life that doesn't crash from Javanese proverb makes for a good life. The view of life in Javanese proverbs has positive criticism to make life better so that humans avoid the bad qualities that exist in proverbs.

The proverb which is a way of life already illustrates that there are two choices that can be chosen by the Javanese people for their lives. The insinuation behind a language which in making our lives will choose the satire to become a better, more peaceful human being and finally get a prosperous life. A prosperous, safe, comfortable life can become a normal life with an ethical, well-behaved life and finally live a life that is in accordance with the Javanese people who are passionate, tolerant and have a high sense of tolerance, care for the people of Java.

\section{References}

Bengat, dkk., 2014. "Ungkapan-ungkapan Jawa Tradisional sebagai Pembentuk Karakter Bansa". Jurnal Ikadbudi, Vol. 3, No. 10

Coles, H. William., 2016. Viewed Illustrated Short Fiction of William. Publisher : storyinliteraryfiction.com

Denzin, K. Norman,et.al., 2009. The elephant in the living room: or extending the conversation about the politics of evidence. Sage Journals

Kuntowijoyo. 2006. Budaya dan Masyarakat. Yogyakarta: Tiara Wacana.

Miles, M. B., Huberman, A. M., Saldana, J., 2014. Qualitative Data Analysis, A Methods Sourcebook, Edition 3. USA: Sage Publications. Terjemahan Tjetjep Rohindi Rohidi, UIPress

Patrick J. M. Costello., 2007. Action Research. ISBN 978082646479-8. Continuum

Prasetyo, G. E., \& Ginting, N., (2019). "Development of Learning Media for Malay Culture with Adore Flast Based on Local Wisdom in Elementary Schools". Basicedu's Journal, 3 (4), 105-113. http://repositorio.unan.edu.ni/2986/1/5624.pdf.

Sahlan, A., 2002. Teori Motivasi dalam pendekatan psikologi industry dan organisasi : Jakarta Studio Press. 
Volume: 7

Nomor : 2

Bulan : Mei

Tahun : 2021

Sawitri, S., Bengat, B., Deswijaya, R. A., \& Priyatiningsih, N. (2019). "Character Value of Proverbs, Sayings and Javanese Saloka as Character Learning for the Next Generation of the Nation". Kawruh: Journal of Language Education, Literature and Local Culture, 1 (2). https://doi.org/10.32585/kawruh.v1i2.407

Sawitri; Priyatiningsih; Bengat; Deswijaya, R. A., \& P. R., N. (2018). Character Value of Proverbs, Sayings, Javanese Saloka.

Sutarman., Haryono, E. Hermawan., Cecep, Hilman., 2016. GUNUNG PADANG CIANJUR: PELESTARIAN SITUS MEGALITIKUM TERBESAR WARISAN DUNIA (Gunung Padang Cianjur: Preservation Of The Largest Megalithic And World Heritage). Jurnal Surya: Seri Pengabdian kepada Masyarakat Volume 2 Edisi 1 Nopember 2016 ISSN2460-576x (cetak).

Sutopo., 2006. Metodologi Penelitian Kualitatif. Surakarta: UNS.

Yanti, R. P. (2018). Multicultural Based Learning in Sociology Subjects. Basicedu's Journal, 2 (2), 70-74. 
글 E-ISSH: 2656-940X (1) P-ISSH: 2442-367K

URL: jurnal.ideaspublishing.co.id
Volume : 7

Nomor : 2

Bulan : Mei

Tahun : 2021 